\title{
Study on the Influence of Bank of Russia on the Banking Sector Liquidity
}

\author{
Nina Morozko \\ Financial University under the Government of the Russian Federation \\ Moscow, Russia \\ E-mail: nmorozko@fa.ru
}

\author{
Natalia Morozko \\ Financial University under the Government of the Russian \\ Federation \\ Moscow, Russia \\ E-mail: nimorozko@fa.ru
}

\author{
Valentina Didenko \\ Financial University under the Government of the Russian \\ Federation \\ Moscow, Russia \\ E-mail: vydidenko@fa.ru
}

\begin{abstract}
An attempt was made to assess trends in the development of liquidity of the banking sector in the context of the needs of the national economy based on an analysis of the evolution of the banking system. The paper reveals the content of liquidity of the banking sector and the formation of the legislative process of its regulation in Russia, associated with the peculiarities of historical development. Special attention is paid to the stability of the banking system directly related to the problem of bank liquidity, which includes a number of subsystems differing in heterogeneity, which necessitated a more detailed study of them both at the theoretical and applied levels through a detailed analysis of the state of the banking sector liquidity regulation system, taking into account on the liquidity of the banking system of the country. The authors propose their own vision of choosing a specific set of conditions for the application of liquidity management instruments, which depends on the unique aspects of the banking system and its type, which are determined by the macroeconomic situation and the main goal of the Russian monetary policy maintaining a stable low inflation rate.
\end{abstract}

Keywords-liquidity; Russia; bank; Bank of Russia; accounts

\section{INTRODUCTION}

The behavior of monetary policy around the world is changing. The past five years have shown that banking systems are experiencing unprecedented losses. The materialization of these events is to reduce lending by commercial banks. In order to maintain financial stability and revitalize lending, the central banks of the United States and Europe reduce interest rates to near zero on loans issued by banks. In response to these actions, unfortunately, there are not many modern macroeconomic models that allow studying monetary policy, implemented by managing the liquidity of the banking sector, taking into account what is happening in practice. In this monograph, we present one of

JEL Classification E58, G21 the possible approaches that fill this gap, because liquidity management is recognized as one of the main problems in banking. We use this approach to answer a number of theoretical questions: how is the influence of autonomous factors on the liquidity of the banking sector and in which development ethanes their manifestation is stronger.

In the economic literature, a significant place is given to the problem of assessing liquidity management as a whole, including bank liquidity. However, the events of the Russian money market in recent years have shown that the Russian banking system is in a state of heightened uncertainty and volatility. Lack of liquidity can cause many consequences a slowdown in lending, interruptions in settlements, and withdrawal from the market of small and medium-sized organizations engaged in lending.

Autonomous factors are one of the key concepts for researchers and employees of central banks involved in the implementation of monetary policy, including the management of bank liquidity. So far, insufficient research has been conducted, the subject of which would be to study the influence of autonomous factors on the liquidity of the banking sector. At the same time, well-known works do not identify the relationship between the liquidity of the banking sector and the degree to which autonomous factors influence the surplus / shortage of liquidity.

This study examines the banking sector liquidity management based on the assessment of the influence of autonomous factors on the surplus/ shortage of liquidity using an array of information requiring analysis and processing, which will allow further research in this area at a fundamentally new level than in previous studies.

The paper substantiates the content of liquidity of the banking sector and the formation of the legislative process of its regulation in Russia, associated with the peculiarities of historical development. In the state monobank system of the 
Soviet economy, liquidity problems and, accordingly, its regulation system were absent.

The paper shows that the stability of the banking system is directly related to the problem of bank liquidity, which includes a number of subsystems with heterogeneity, which necessitated a more detailed study of them both at the theoretical and applied levels through a detailed analysis of the state of the system for regulating liquidity of the banking sector affecting the liquidity of the country's banking system.

The analysis and assessment of the liquidity of the banking system were carried out through the prism of the targets set out in the work of its operation: indicators of the state of liquidity of the banking sector in 2014-2017; Bank of Russia operations for the provision and absorption of ruble liquidity; dynamics of autonomous liquidity factors of the banking sector.

The paper presents a model that allows you to answer a number of theoretical questions: how is the influence of autonomous factors on the liquidity of the banking sector, finding the optimal combination between the credit and deposit policies of commercial banks, etc.

On the basis of the panel regression apparatus, it is shown that among the autonomous factors of liquidity formation, the change in the balance of funds in the extended government accounts with the Bank of Russia has the greatest impact on the amount of liquidity in the Russian banking sector.

The authors propose to focus on the redistribution of liquidity between market participants through bank lending.

The use of the model requires the creation of a mechanism for selective action, and not impeding the solution of the problems of the main trend of economic development.

The study will allow the Central Bank to predict the need and determine the potential of the banking sector in liquidity, taking into account the influence of autonomous factors.

The results showed that the choice of a specific set and conditions for the application of liquidity management tools by the Central Bank depends on the unique aspects of the banking system and its type, which are determined by the macroeconomic situation and the main goal of the Russian monetary policy - maintaining stable low inflation rates.

\section{LITERATURE REVIEW}

In the economic literature, a significant place is given to liquidity problems in general, including bank liquidity.

The relevance of the study is confirmed by the growing attention to the management of liquidity in the banking system. The events of the Russian money market in recent years have shown that the domestic banking system is in a state of heightened uncertainty and volatility.

Nevertheless, the liquidity of the banking system is a complex concept that does not have an unambiguous definition. At the moment in the economic literature there is no single theory of the formation of bank liquidity.

The term tiquidity" is derived from the word that comes from the English Liquidity and the French Liquidite and is closely associated with the Latin word tiquidus", which means fluid, liquid.

The main moments of liquidity were reflected in the financial literature, and with the formation of commercial banks, and essentially used only in the banking aspect. The definition of bank liquidity is multivalued.

Some authors give a general concept of bank liquidity, emphasizing the need to maintain a competitive position of the bank in the market.

Thus, the French economist P. Dieterlin understands by her the totality of cash present in the present and which can be obtained in the future, opposing all current needs and obligations that are required immediately or in a short time. The English economist J. Keynes in his work The General Theory of Employment, Interest and Money" introduces the concept of tiquidity preference": $\ldots$. the preference of an individual's liquidity is given by a schedule that describes what quantities of its resources (estimated in money or wage units) this individual wishes to keep in the form of money in various situations" $[5]^{\mathrm{p}-62}$.

The American economist R. Holt identified the bank's liquidity with $\rightarrow$ set of bank cash opposing an outflow of funds for current needs and a bank's repaying liabilities at any time" $[11]^{\mathrm{p}-127}$ Or A. Fournier, who considered banking liquidity as an opportunity to recount funds in the Central Bank" $[11]^{\mathrm{p}-129}$.

Until 1917 , the term liquidity was not used in banking literature. In the Soviet economic literature of the 1920s, the concept of liquidity" was used to evaluate the own and working capital of an enterprise and to properly use its own and borrowed funds.

At present, there is no consensus in the economic literature that reveals the essence of the concept of liquidity in the banking system.

When conducting a categorical analysis of this concept, it was revealed that A. Kurakie, a professor at Oxford University, understands the liquidity of the banking system as the ownership of banks by the funds of the central bank and short-term assets that can be used to increase these funds. Professor of the University of London R. Somers believes that liquidity is the ability of banks to meet the demand for cash in exchange for dividends. American economist D. Lucket — the ability of banks to return depositors' funds upon their request. In all the above definitions, one-sidedness, incompleteness of expression of the essence of bank liquidity can be traced.

The main approach of the Bank of Russia to the management of ruble liquidity and related concepts. submitted to the materials of the official site of the Bank of Russia: $\Theta n$ the determination of limits on market operations of the Bank of Russia on the provision (absorption) of liquidity". The volume of ruble liquidity of the banking 
sector "is understood as the sum of balances in correspondent accounts of credit institutions with the Bank of Russia as the most liquid funds of credit organizations to which they can quickly access and which they use to carry out banking activities."

The liquidity of the banking sector is the balances of credit institutions in the correspondent accounts at the central bank used by them for banking activities, including settlements and payments.

At the same time, in the literature, as far as we know, the liquidity risk of the central bank was not considered. This is mainly due to the widespread belief that the liquidity risk of the central bank does not exist, since the central bank is always able to provide basic money and, therefore, can never be illiquid. Usually, the central bank, which is the monopoly liquidity provider that forms the monetary base, can distribute liquidity as needed to satisfy the equilibrium demand for liquidity in the banking system (avoiding excess liquidity or liquidity deficit) in accordance with its policy. The central bank can be illiquid only to the extent that there is no demand for domestic currency; therefore, the delivery of base money from the central bank could not be realized. However, based on common wisdom, such a scenario could be considered unlikely, at least in developed, industrialized countries and, therefore, is not considered in the literature.

It would also be useful to emphasize that the central bank may incur costs in its role as a liquidity provider, but these costs do not necessarily increase the liquidity risk. Such expenses may be related to specific risks of the central bank (for example, the counterparty's credit risk on collateral value), monetary policy risks or broader risks to financial stability (i.e. turbulence conditions). However, these risks do not affect the ability of the central bank to provide liquidity. The term liquidity of the central bank is understood to mean the ability of the central bank to provide the liquidity necessary for the financial system. It is usually measured by the sum of balances of credit institutions in correspondent accounts with the central bank used by them for banking activities, including settlements and payments. This refers to the liquidity of central bank operations, which refers to the amount of liquidity provided at central bank auctions and the money market in accordance with the position of monetary policy. The latter reflects the prevailing value of the operational goal, that is, the control variable of the central bank. In practice, the strategy of the central bank determines the position of monetary policy, that is, determines the level of operational objectives (usually the key policy rate). To achieve this goal, the central bank uses its monetary policy tools (conducts operations on the open market) to maintain liquidity in the money market. From a technical point of view, the liquidity of the central bank is synonymous with a base money offer.

As noted, in Russia, liquidity includes the amount of balances on correspondent accounts of credit institutions with the Bank of Russia. The volume of liquidity in the banking sector changes as a result of:
- actions of autonomous factors (i.e., factors that are outside the framework of the central bank's liquidity management policy of the banking sector),

- as a result of the operations of the provision and absorption of funds by the central bank,

- regulation of mandatory reserves of credit institutions.

In modern economic conditions, bank liquidity should be considered as a multi-level category system that contains the structural elements:

- liquidity of the banking system;

- bank liquidity;

- balance sheet liquidity;

- liquidity of assets;

- liquidity of liabilities.

Lack of liquidity is the excess of the banking sector's demand for liquid assets over their supply, which is generated only by autonomous factors that are independent of the central bank's activities. It sometimes arises temporarily - in the event of tax collection, when funds accumulate in the accounts of the expanded government; then the accumulated funds are returned to the economy in the form of government spending, fall into the banking sector and eliminate the liquidity deficit. If the liquidity deficit acquires a steady state and persists regardless of seasonal factors, it is structural and threatens the country's economy.

A significant factor in the formation of liquidity is the change in the balances of funds in the extended government accounts with the Bank of Russia. A significant and sustained outflow of capital from the country, which is currently happening in the Russian Federation, may have a greater impact.

In another definition, the main focus is on cash and other assets that can be converted into cash or non-cash funds as soon as possible: liquidity of the banking system is the ability to ensure timely execution of all debt obligations to depositors, creditors and founders of banking institutions, the ability to attract in full free funds of businesses and individuals, to provide loans and invest in the development of the country's economy.

The documents of the Central Bank of the Russian Federation provide a definition that takes into account the sufficiency of funds in the economy. The liquidity of the banking sector is considered as Bank of Russia funds of credit institutions that are maintained on correspondent accounts in order to carry out payment transactions and meet reserve requirements.

It follows that the essence of banking liquidity in the economic literature and practice can act in two aspects:

- liquidity in the narrow sense is cash and other highly liquid assets that can quickly turn into cash or noncash money and are used to timely repay liabilities and provide loans; 
- in a broad sense, liquidity is a means of ensuring the sufficiency of funds in the economy and the uninterrupted operation of payment systems and commercial banks

To understand the essence of the liquidity of the banking system, it is necessary to consider the factors that influence it:

- the activity of credit institutions, which is determined by the needs of the economy - the demand for banking services from the population and the real sector of the economy;

- the degree of development of the system of interbank relations, which is caused by the situation related to the activity on the interbank credit market and the level of interbank trust

Thus, the most complete is the definition of bank liquidity as the amount of settlement and payment funds within the banking system, necessary for the stable functioning of the entire banking system and the economy as a whole, based on a developed system of interbank relations.

This definition most accurately reflects the nature and economic essence of the concept. Therefore, it is advisable to take it as a basis for the study.

Under the influence of various factors, a shortage or excess of liquidity of the banking system can form

The structural lack of liquidity in the banking sector is the state of the banking sector, which is characterized by the existence of a stable need for credit institutions in attracting liquidity through operations with the Bank of Russia. The opposite situation - the presence of a stable need for credit institutions in placing funds in the Bank of Russia - is a structural surplus of liquidity.

The structural surplus of liquidity means that the banks are getting so much money that they are no longer interested in raising funds from the Central Bank, but, on the contrary, are its creditors, placing excess liquidity on deposits and correspondent accounts.

The lack of a structural surplus lies in the fact that the Central Bank partially loses control over the liquidity management process, since it cannot influence the banking sector with an interest rate. This means that the regulator's ability to control monetary policy is diminished, since currently, there are large banks that are practically independent of the resources of the Central Bank and provide long credit resources at a rate lower than the deposit rate of the Central Bank.

In order to absorb liquidity coming into banks from the budget, the Central Bank, in addition to OFZ sales, can also lower the limits on auction instruments, which will allow withdrawing a certain amount of funds from the banking system, but this is not enough. It should be noted that deposit auctions are less efficient instrument, because the demand for such instruments will be only if the banks are confident that the ruble will not weaken, and the rates on long-term instruments will decrease. With further growth in the level of ruble liquidity, a situation may arise when banks begin to place more funds on correspondent accounts and deposits of the Central Bank than they attract from the regulator for repos and loans secured by non-market assets.

The structural liquidity surplus will create problems for the Bank of Russia to manage the short-term interest rate of the money market and keep it close to the key rate

Problems created by structural liquidity surplus:

- for the implementation of a symmetrical interest corridor system, it is required to absorb liquidity at an interest rate equal to the key rate;

- absorption of liquidity costs the central bank significant losses in financial performance;

- experience shows that in conditions of structural surplus

Liquidity The Bank of Russia was unable to completely absorb excess liquidity, the market short-term interest rate was significantly below the center of the interest rate corridor.

It should be noted that another problem of the structural liquidity surplus is that the Central Bank incurs significant interest expenses in liquidity absorption operations, which reduce its profit.

The main objective of the Bank of Russia liquidity management operations is to ensure a balance of liquidity in the banking system.

Thus, summarizing the data on the categorical analysis, the definition of banking sector liquidity was proposed, it was clarified that banking liquidity has several sources of formation:

- budget operations

- currency operations,

- change in cash in circulation.

It should be particularly noted that covering the liquidity deficit in the banking sector is due to a number of reasons that complicate the decision by the Bank of Russia.

First, in Russia, the main autonomous factor in the formation of liquidity is the change in budget balances in the extended government accounts, and the amount of budget funds largely depends on highly volatile energy prices. In addition, the expenditure of budgetary funds during the year is very uneven. The unevenness of budget spending is due to the lack of efficiency in the implementation of the public procurement procedure for goods and services from both ministries and departments in the selection of projects and from economic agents in the execution of government orders, as well as little experience in budget planning.

Secondly, the distribution of funds in the interbank market is not always efficient, since the Russian interbank lending market is segmented, i.e. a significant part of operations is carried out between a limited number of banks linked by common business interests 
Thirdly, because of the relatively limited (as compared with developed countries) list of securities accepted for repos and lombard lending. Many banks still do not have access to these operations, which are the main operations for providing liquidity to the Bank of Russia. The list of securities is limited due to the insufficiently high degree of development of the Russian financial market in comparison with developed countries.

As a result, it is difficult for the Bank of Russia to accurately predict the need of the banking sector for liquid funds, as a result of which it is forced to establish and maintain a fairly large spread between the rates that determine the upper and lower limits of the interest rate corridor.

\section{Methodology}

Key changes in the regulation of liquidity of the national banking sector since the 1990s.

The formation of the legislative process of regulation of the banking sector of Russia is associated with the peculiarities of its historical development. In the state monobank system of the Soviet economy, liquidity problems and, accordingly, its regulation system were absent. However, despite the insolvency, most banks remained liquid, using the central bank refinancing and customer confidence. The origins of banking legislation were the two laws adopted at the end of 1990 - the Law on the State Bank and the Law on Banks and Banking. Approximately half of the cooperative banks (767) were reissued into commercial banks. About 650 new commercial banks were opened by the beginning of 1992. The majority of commercial banks were small. Not only general political and economic factors, but also lack of unity in the methods of banking regulation, had a noticeable effect on the destabilization of monetary circulation. Nor were the instruments of monetary regulation uniform. In essence, the relationship between the Central Bank of the RSFSR and commercial banks resulted in a conflict situation. Commercial banks were not satisfied with the cumbersome procedure of their registration, unsatisfactory supply of cash, while the Central Bank did not have money either, and it could not back up their cash balance, because the money did not make the necessary circulation due to the trade deficit, settled in the hands of the population. The restrictive monetary policy conducted by the Central Bank of Russia in 1993-1996, allowed not only to reduce inflation and the emergence of liquidity losses of many large banks in 1995-1996, as evidenced by statistics:

- for four years from the beginning of 1993. until the end of 1996 there was an excess of the total resources of commercial banks located in the Central Bank of Russia over centralized loans to commercial banks;

- the size of this excess increased. This suggests that after 1992. The Central Bank of Russia at an increasing pace produced a withdrawal of resources from the banking system

In the lending of the real sector were involved in the accounts on demand. As of June 1, 1996, about half of commercial bank loans were financed with demand deposits, which led to a critical gap between the privatization terms.

As a result, during 1993-1995, liquidity indicators of the banking system fell fourfold: coverage of balances on ruble accounts and deposits with liquid assets of banks decreased from 47 to $12 \%$, the ratio of liquid assets to the amount of loans issued from 46 to $12 \%$. This indicates a downward trend in the liquidity of the banking system due to the credit expansion of banks.

Coverage of the budget deficit after 1995. This happened at the expense of state loans and in each subsequent year the budget funds to cover state loans increased, i.e., a government loan pyramid was built. The state has temporarily suspended the repayment of government bonds. These macroeconomic factors triggered the 1998 crisis. In the banking sector, assets had a large share of government securities purchased, which were the main source of income for commercial banks. Since the assets were not diversified, this led to a loss of liquidity and solvency of many banks.

Among the prerequisites of the -risis of confidence in 2004" are the reduction in liquidity associated with a tightening of monetary policy and an increase in the demand for dollar assets. In 2007, the Bank of Russia began using tools to replenish bank liquidity in the money market. Regulation No. $312-\bigoplus$ n the procedure for the provision of loans secured by assets by the Bank of Russia to credit institutions" was put into effect, which at that time was supposed to provide medium-term funding for banks against the pledge of the loan portfolio. At the same time, the excess gross liquidity of banks (balances on correspondent accounts and deposits with the Bank of Russia) exceeded the norm by more than two times. The main factors that caused the liquidity boom were the IPO of VTB and Sberbank's SPO, the auction of YUKOS property and the influx of foreign capital into the stock market. However, in the second half of 2007, the situation reversed. As a result of the unfolding US mortgage crisis, a sharp decline in liquidity began in the Russian banking sector, due to a reduction in the inflow of money from abroad. One-day direct repo operations became instruments of increasing liquidity, the total limit for these operations in the fall of 2007 was expanded to 500 billion rubles. In September 2008, the rates on the interbank lending market for medium and small banks rose to $40 \%$. Borrowing money on the security of securities also became problematic. One of the reasons - a sharp drop in the value of shares. So, on September 16, 2008, the MICEX index collapsed by $17.45 \%$, the RTS index collapsed by $11.47 \%$. Not only stocks, but also promissory notes, including state OFZs, fell in price.

At this time, taking into account the international experience of regulation and supervision, the Committee for Banking Regulation adopted the following documents:

- in 1988: International Convergence in Capital Measurement and Capital Standards" (-Basel I"), which was based on an administrative approach to risk assessment and to capital adequacy requirements; 
- in 2004: International Convergence in Capital Measurement and Capital Standards: Refined Framework Approaches" (Basel II"). The main objective of the Basel II agreement is to improve the quality of risk management in banking, which in turn should strengthen the stability of the financial system as a whole.

At the beginning of 2011, the Russian banking sector accumulated a large amount of excess liquidity - about 2-3 billion rubles. Most of the liquid funds were concentrated in the accounts of the Bank of Russia, including deposit accounts with the Central Bank of the Russian Federation, the amount of funds in which in January 2011 averaged almost 900 billion rubles.

Since 2011, qualitative changes have occurred in the monetary policy of the Bank of Russia:

- refusal of intervention of the Central Bank of the Russian Federation in the process of market pricing in the foreign exchange market;

- set for short-term repos — the main instrument of monetary policy;

- along with operations for the provision and absorption of liquidity, which are provided constantly, weekly REPO operations on an auction basis form the so-called interest rate corridor, through which the Bank of Russia manages the money market;

- the task of stabilizing inflation at a low level.

During 2011-2014 the banking system was in a state of growing liquidity deficit. The lack of financial resources was due to the active growth of the loan portfolio. During this period, there was an active growth in consumer lending, and the inflow of customer funds into banks was insufficient due to the general deterioration of the economic situation and the imposition of sanctions. In this situation, banks began to intensively attract resources provided by the federal treasury and the Bank of Russia.

It should be noted that in 2015 the situation began to change radically: after the Central Bank of the Russian Federation sharply raised the key rate in 2014, its subsequent decrease in 2015 occurred more slowly than the average deposit rates for bank customers decreased - as a result, the attractiveness of raising funds from the Bank of Russia decreased, because in a situation of shrinking economic growth and with high rates, customers changed their behavior strategy:

- corporate clients reduced investment activity (according to Rosstat, investment in fixed assets in 2015 decreased by $8.4 \%$ );

- individuals have reduced the cost of purchasing expensive goods.

In 2015, the following tools were used to manage the liquidity of the banking system of Russia: a mechanism for issuing subordinated loans, placing federal funds on banks' deposits, issuing loans of the Bank of Russia without collateral, lombard loans and concluding direct repo transactions.

However, starting from April-May 2016, an increase in ruble liquidity in the banking sector began to be observed According to the results of 2015, the assets of commercial banks increased by $6.9 \%$, the volume of deposits of individuals - by $25.4 \%$, funds of legal entities - by $11.8 \%$, and capital - by $13.6 \%$, i.e. the increase in the volume of the resource base overtakes the dynamics of active operations. The change in trend is also confirmed by a sharp decrease in banks' debt on repo transactions in rubles to the Central Bank. This testifies that objective prerequisites have been formed for the formation of excess liquidity in the banking sector [5]:

- the demand of banks for loans provided by the Central Bank decreased (over 4 months of 2016, the volume decreased by $42.2 \%$ );

- the profitability of deposits of individuals decreased; according to the Central Bank of the Russian Federation, the maximum rate of the 10 largest banks from the beginning of 2015 to the end of May 2016 decreased from $15.33 \%$ to $9.76 \%$ per annum;

- there were deviations of yield-urgency" on deposits, starting in 2015, Russian banks began to massively set the profitability of deposits in inverse proportion to their level of urgency;

- the stabilization of the ruble exchange rate in mid2015 stimulated a reduction in purchases of cash currency, and the return of public confidence in banks contributed to a reduction in the volume of ruble cash in circulation, which provided an additional inflow of funds into the banking system.

Conclusion: a study of the development of the regulatory system of the national banking sector of Russia shows that the choice of a specific set and conditions for the use of liquidity control instruments by the Central Bank depends on the unique aspects of the banking system and its type, which are determined by the macroeconomic situation and the main goal of the monetary policy of the Russian Federation maintaining stably low inflation rates.

\section{A. Data and Variable Framework}

The concept of autonomous factors reflects the specificity of a number of functions of the central bank as an institution with a special status, a side effect of which is a change in the volume of total bank reserves. The implementation by the central bank of the emission function and the function of the government agent is initiated by other economic entities (credit organizations, government bodies), and the float arising from its function of organizing payment transactions is a consequence of the payment system. The volatile and uncertain nature of the operations carried out within these functions, as well as the necessity of their execution, lead to an uncontrollable (autonomous relative to the central bank) change in the volume of bank reserves, which should subsequently be compensated using monetary 
policy instruments. In the case when the central bank makes independent, independent decisions on the implementation of operations that are not related to monetary policy, but affecting bank reserves, the responsibility for them should be fully vested in the regulator, and there is no reason to talk about autonomous factors.

The main factors of demand are:

- changes in balances on correspondent accounts with the Bank of Russia;

- changes in the requirements of credit institutions for deposits with the Bank of Russia.

The net volume of Bank of Russia operations for the provision and absorption of liquidity (excluding interventions in the domestic foreign exchange market) is calculated at the end of the day as the difference between the change in Bank of Russia liabilities to the banking sector and the change in Bank of Russia requirements for the banking sector for the current day. In addition, the calculation of this indicator includes the balance of operations of the Bank of Russia on the purchase / sale of securities in the secondary market without a repurchase / purchase obligation.

By the Bank of Russia, the need of credit institutions for liquidity, that is, cash on correspondent accounts with the Bank of Russia, is determined by customer and own payments and calculations and the need to fulfill the required reserve requirements. Required reserve requirements include required reserve ratios and averaging factor of required reserves. The Bank of Russia sets the required reserve ratios based on the objectives of managing the banking sector's liquidity. At the same time, standards for ruble obligations of credit institutions have a more significant effect on liquidity. The mechanism of averaging required reserves, according to which a credit institution is required to maintain a certain balance in accounts not every day, but only on average for a period, allows banks to flexibly manage liquidity. At the same time, the volume of liquidity in the banking sector is constantly changing under the influence of various factors, including budgetary flows and the population's demand for cash. To meet the liquidity needs of credit institutions, the Bank of Russia conducts operations to provide it, and in case of excess liquidity, operations to absorb it. By providing or absorbing the required amount of liquidity, the Bank of Russia creates conditions for the formation of rates near the key rate. The volume of transactions is determined on the basis of the banking sector liquidity forecast.

In 2015-2016, the federal treasury and constituent entities of the Russian Federation placed funds on deposits much more actively, which was one of the sources of liquidity inflow at the beginning of the calendar year.

In general, in 2016, in conditions of a significant change in the scale of the structural liquidity deficit of the banking sector, Bank Rossi In 2016, due to the financing of the budget deficit at the expense of the Reserve Fund, it became possible to switch from a structural deficit to a structural liquidity surplus from 2017. This means that the amount of funds in correspondent accounts of banks with the Bank of
Russia has become higher than the level necessary for them to carry out their current activities.

The Bank of Russia's liquidity forecast for the banking sector for the future is based on a study of factors, for example, in 2016, the following factors reduced the need for refinancing:

- the use of the Reserve Fund and the investment of the National Wealth Fund,

- transfer of DIA funds for the rehabilitation of banks and the payment of insurance compensation to depositors,

- accounting for early repayment of loans (312-P) as the structural deficit decreases

As well as the structural lack of liquidity, the structural excess of liquidity does not directly affect the credit activity of banks. The dynamics of the loan is determined primarily by the ratio of its supply and demand. The supply of credit depends on the situation in the economy as a whole and on the credit markets in particular, the degree of riskiness of investments, regulatory requirements. The demand for loans from enterprises and the public is determined by their confidence in the future, the assessment of the economic outlook, expected income, the level of interest rates and other factors. At the same time, lending to the real sector of the economy practically does not lead to a change in the aggregate level of liquidity in the banking sector. In the case of a loan, funds are transferred by the creditor bank to the borrower's account in another bank, that is, the funds are redistributed between the banks' accounts, and the total liquidity level does not change.

It follows that in order to manage liquidity, the Bank of Russia estimates the demand for liquidity and its supply. Liquidity supply is formed by: the action of autonomous factors of liquidity formation (AFFL), i.e. factors outside the direct control of the central bank liquidity management system. The demand for liquidity is determined by: the need of the banking sector in averaging the required reserves. The need for funds for the calculations.

Under the conditions of a structural liquidity surplus, credit institutions will seek to place surplus funds. In this regard, in the coming period, the main instruments of monetary policy will be deposit auctions for a period of 1 week.

The system of monetary policy instruments of the Bank of Russia used in the conditions of a structural surplus of banking sector liquidity makes it possible to prevent excessive fluctuations in short-term money market rates and keep them near the key rate.

In a situation of a structural liquidity surplus, the Bank of Russia, in accordance with the articles of the Bank of Russia Law and the Bank of Russia Regulation on Deposit Operations with Credit Institutions, can conduct operations to raise funds of a credit institution into deposits (deposit operations). 
Bank of Russia operations on binding (absorption) of excess liquidity on a returnable basis are carried out in the forms:

Raising funds of credit institutions in deposits in accordance with points 4, 46, 62.1 of the Law on the Bank of Russia and the Regulation on the Bank of Russia to conduct deposit operations with credit organizations, approved by the Bank of Russia of 09.08.2013 No. 404-P, and the Information Letter on the procedure for the Bank of Russia of deposit operations of March 28, 201 No. IN-01- 20/16.

Deposit operations are understood as the Central Bank of the Russian Federation attracting cash from commercial banks to deposit accounts with the Bank of Russia in order to regulate the liquidity of the banking system. Based on the definition, the subjects of deposit operations are the Central Bank of the Russian Federation and resident banks of the Russian Federation.

This type of operations allows commercial banks to receive income from free or excess reserves, and the Central Bank - to influence the size of the money supply, namely, to withdraw excess money by attracting deposits.

Currently, in order to absorb liquidity of the banking sector, it is planned to:

$$
\operatorname{Ln} A_{\text {corresp }}=\beta_{0}+\beta_{1} \ln \text { Money } \text { circulation }+\beta_{2} \ln A_{\text {government }}+\beta_{3} \ln L i q_{C B}+\mu
$$

$\operatorname{Ln} A_{\text {corresp }}$ - funds of credit institutions in correspondent accounts with the Bank of Russia

LnMoney $_{\text {circulation }}$ - change in cash in circulation (outside the Bank of Russia)

$L n A_{\text {government }}$ - changes in the balances of funds in the extended government accounts with the Bank of Russia and other operations

$\operatorname{LnLiq}_{C B}$ - the net volume of Bank of Russia operations for the provision and absorption of liquidity (excluding operations in the domestic foreign exchange market)

\section{B. Interpretation Results} statistics of the central bank. correlation matrix, and autocorrelation. correlation matrix in "Table I".
- deposit operations at fixed interest rates on standard terms as permanent operations to absorb liquidity (carried out daily);

- deposit auctions for a period of one week in accordance with the schedule of holding deposit auctions and on the basis of the decision of the Bank of Russia to hold a deposit auction - as the main tool for absorbing liquidity of the banking sector. In accordance with the Regulation dated 09.08.2013 No. 404-P, in addition to conducting interest-based auctions by -Arerican" or Đutch" methods, the Bank of Russia can conduct bulk deposit auctions. If necessary, the Bank of Russia can promptly conduct deposit auctions for periods ranging from one to six days as a fine tuning" tool.

- placement of Bank of Russia bonds. The Bank of Russia can hold auctions to place its own bonds to reduce the burden on core operations - weekly deposit auctions, that is, if excess liquidity is formed in a significant amount and for a long time.

To show the elasticity of the dependent variable with respect to the dependent variables, the log-ratio should be used:

The data for the study were obtained from the national

Before launching the regression equation, the following tests were carried out: stationarity, multicollinearity using a

The results of the correlation tests are presented by the

TABLE I. CORRELATION MATRIX

\begin{tabular}{|c|c|c|c|c|}
\hline & $\begin{array}{l}\text { funds of credit } \\
\text { institutions in } \\
\text { correspondent } \\
\text { accounts with the } \\
\text { Bank of Russia }\end{array}$ & $\begin{array}{l}\text { change in cash in } \\
\text { circulation (outside } \\
\text { the Bank of } \\
\text { Russia) }\end{array}$ & $\begin{array}{l}\text { changes in the balances } \\
\text { of funds in the extended } \\
\text { government accounts } \\
\text { with the Bank of Russia } \\
\text { and other operations }\end{array}$ & $\begin{array}{l}\text { the net volume of Bank of Russia } \\
\text { operations for the provision and } \\
\text { absorption of liquidity (excluding } \\
\text { operations in the domestic foreign } \\
\text { exchange market) }\end{array}$ \\
\hline $\begin{array}{c}\text { change in cash in circulation } \\
\text { (outside the Bank of Russia) }\end{array}$ & 0,066655207 & & & \\
\hline $\begin{array}{c}\text { changes in the balances of funds in } \\
\text { the extended government accounts } \\
\text { with the Bank of Russia and other } \\
\text { operations }\end{array}$ & $-0,017213888$ & 0,007270639 & & \\
\hline $\begin{array}{c}\text { the net volume of Bank of Russia } \\
\text { operations for the provision and } \\
\text { absorption of liquidity (excluding } \\
\text { operations in the domestic foreign } \\
\text { exchange market) }\end{array}$ & $-0,036188296$ & 0,009260075 & 0,001896338 & \\
\hline
\end{tabular}

Correlation analysis showed that the relationship between variables is extremely low. The amount of funds of credit institutions in correspondent accounts with the Bank of Russia does not depend on these operations of the Bank of
Russia. The increase in volumes on correspondent accounts causes an increase in cash in circulation by $10 \%$. Reduction in government accounts by $1 \%$ and reduction in Bank of Russia liquidity operations by $3 \%$ in "Table II". 
TABLE II. REGRESSION STATISTICS

\begin{tabular}{|c|l|c|c|}
\hline \multicolumn{4}{|c|}{ Regression statistics } \\
\hline Multiple $\boldsymbol{R}$ & 0,078157 & $\begin{array}{c}\text { Normalized } \\
\text { R-square }\end{array}$ & 0,004094 \\
\hline R-square & 0,006109 & $\begin{array}{c}\text { Standard } \\
\text { error }\end{array}$ & 0,364622465916329 \\
\hline Observations & 1484 & \\
\hline
\end{tabular}

Regression statistics show the unreliability of the relationship of the variables in question, while the number of observations is 1,484 . This confirms the fact that the Bank of Russia has no influence on the appearance of liquidity in the banking sector.

The coefficients for the variables of the formed equation have the following form in "Table III".
TABLE III. REGRESSION COEFFICIENTS

\begin{tabular}{|c|c|}
\hline & coefficients \\
\hline Y-intersection & 6,893626 \\
\hline $\begin{array}{c}\text { change in cash in circulation (outside the Bank of } \\
\text { Russia) }\end{array}$ & 0,002134 \\
\hline $\begin{array}{l}\text { changes in the balances of funds in the extended } \\
\text { government accounts with the Bank of Russia and } \\
\text { other operations }\end{array}$ & $-0,00022$ \\
\hline $\begin{array}{c}\text { the net volume of Bank of Russia operations for the } \\
\text { provision and absorption of liquidity (excluding } \\
\text { operations in the domestic foreign exchange } \\
\text { market) }\end{array}$ & $-0,00037$ \\
\hline
\end{tabular}

Analysis of variance shows the following situation. The model does not describe the liquidity policy in the banking sector, despite the obvious relationship between the regulator, which acts as a lender of last resort, and the banking sector in "Fig. 1", "Fig. 2", "Fig. 3" and "Table IV".

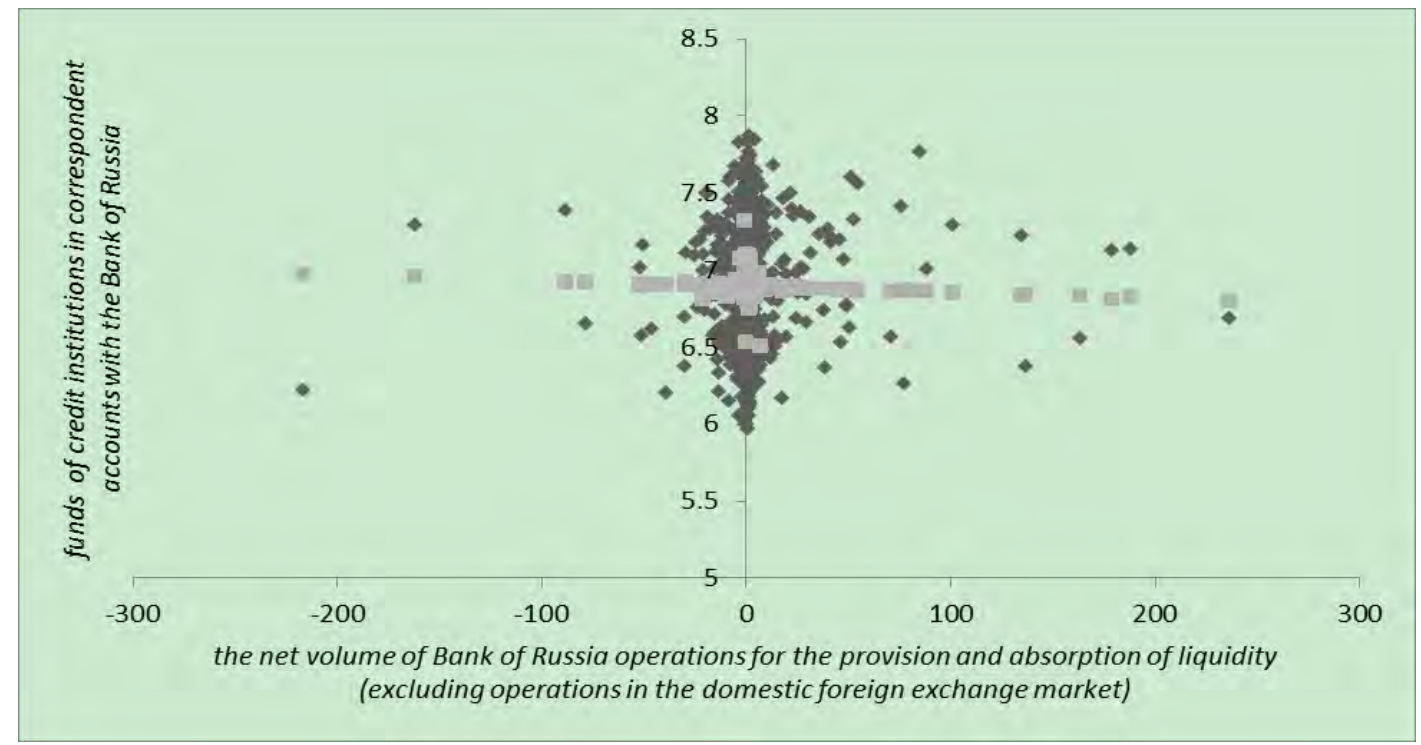

Fig. 1. The net volume of Bank of Russia operations for the provision and absorption of liquidity (excluding operations in the domestic foreign exchange market).

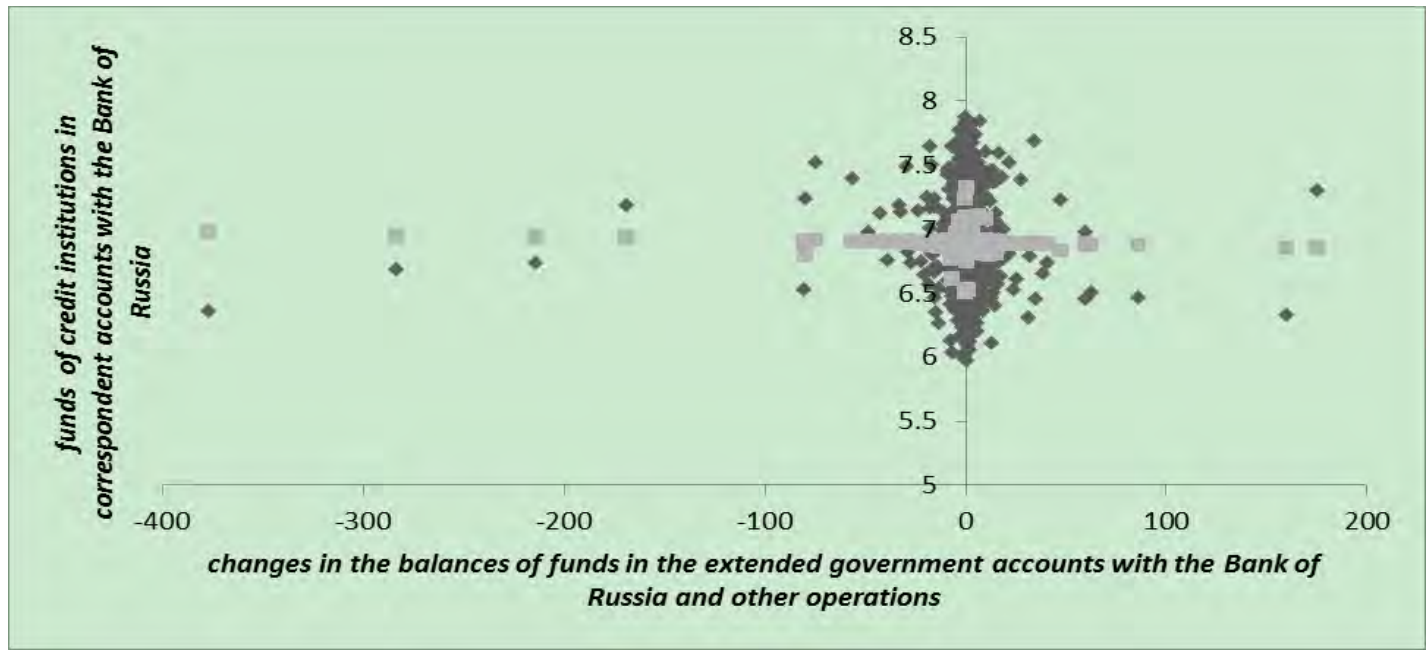

Fig. 2. Changes in the balances of funds in the extended government accounts with the Bank of Russia and other operations. 


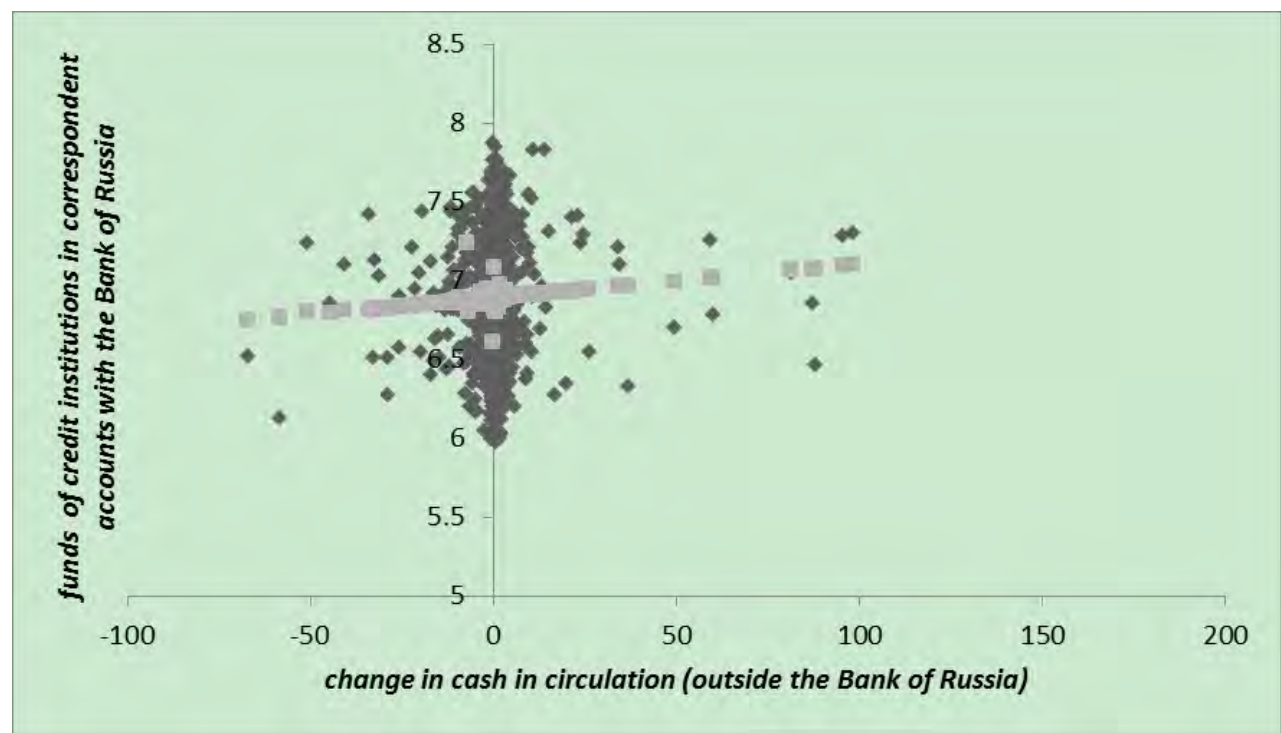

Fig. 3. Change in cash in circulation (outside the Bank of Russia).

TABLE IV. DISPERSION ANALYSIS

\begin{tabular}{|c|l|c|c|c|c|}
\hline & df & \multicolumn{1}{|c|}{ SS } & MS & F & $\begin{array}{c}\text { Significance } \\
\text { F }\end{array}$ \\
\hline regression & 3 & 1,209339 & 0,403113 & 3,032076 & 0,028356 \\
\hline residual & 1480 & 196,7653 & 0,13295 & \multicolumn{2}{|c}{} \\
\hline sum & 1483 & 197,9747 & & & \\
\hline
\end{tabular}

Consider the plots of residuals. The graphs show the deviations from the observed values of the prediction are the opposite.

\section{CONCLUSION}

A study of the current state and liquidity of the banking sector in the interests of the national economy showed that it needs modernization not only due to the urgent need to form balanced liquidity, but the contradictory goal - to provide business entities with credit resources and meet the needs of the Central Bank, which implements policy in targeting mode inflation.

An analysis of the theoretical work, as well as the practice of central banks, including the Bank of Russia, on managing the liquidity of the banking sector made it possible to draw the following conclusions:

- The work substantiates the content of liquidity of the banking sector and the formation of the legislative process of its regulation in Russia, associated with the peculiarities of historical development. Throughout its development, the banking sector was in a state of shortage and surplus of liquidity. A number of reasons have been identified that complicate the decision by the Bank of Russia to preserve balanced liquidity in the banking sector. The lack of accuracy in forecasting the needs of the banking sector for liquid assets forced the Bank of Russia to establish and maintain a fairly large spread between the rates that determine the upper and lower limits of the interest corridor.
- It was revealed that the choice of a specific set and conditions for the use of liquidity control instruments by the Central Bank depends on the unique aspects of the banking system and its type, which are determined by the macroeconomic situation and the main goal of the monetary policy of the Russian Federation - maintaining stable low inflation rates. In this, the most important role is played by the alignment of monetary policy tools and procedures, ensuring that the volumes of its operations in the open market match the expected liquidity needs of the banking sector and smooth out random liquidity shocks with the help of permanent operations.

- A study of the development of the regulatory system of the national banking sector of Russia showed that the choice of a specific set and conditions for the use of liquidity control instruments by the Central Bank depends on the unique aspects of the banking system and its type, which are determined by the macroeconomic situation and the main goal of the Russian monetary policy inflation rates.

- The analyzed period demonstrated that the government's policy to support the banking system was aimed at increasing its capital, supporting liquidity and improving individual banking organizations. In the period 2014-2016, on the one hand, the regulator's requirements for banks were relaxed, on the other hand, the number of revoked licenses increased significantly. Thus, although by now the direct impact of external shocks has weakened, problems in the banking system persist and require new approaches to solve them.

- Considered the reasons for the formation of excess liquidity - reducing creditworthy demand for monetary resources. The strengthening of the ruble, caused by rising oil prices, prevents banks from channeling liquidity into the foreign exchange market. 
The stock market is also a little attractive for banks. If several months ago the Central Bank was the main source of liquidity for the banking sector, now it has lost this function. The greatest contribution to reducing the structural liquidity deficit in 2015 was made by the changed parameters of fiscal policy.

\section{REFERENCES}

[1] Morozko, Nina, Morozko, Natalia, Didenko, Valentina (2018). Determinants of the savings market in Russia. Banks and Bank Systems, 13 (1), 196-208.

[2] Specificity of Bank of Russia operations with foreign currencies Morozko NI, DidenkoV.Yu. Collection of scientific papers of Russian universities "Problems of economics, finance and production management." 2018. No. 42. P. 41-47.

[3] Morozko N.I., Shogenova F.O. Contact banking supervision: problems and ways of development Monograph / Moscow, 2017.

[4] Morozko N.I. Problems of inconsistencies in the management of liquidity by the regulator and commercial banks. Questions of economic sciences. 2017. No. 3 (85). Pp. 33-34.

[5] Morozko N.I. Tools of state regulation of liquidity of the banking system of Russia in the conditions of economic recession Audit and financial analysis. 2016. No. 4. P. 391-393.

[6] Morozko N.I. Management and forecasting of liquidity of the Russian banking system Economics. Business. Banks. 2016. № 4 (17). Pp. $24-$ 34.

[7] Nevolina E.V. The concept of bank liquidity / E.V. Nevolina // Money and Credit. - 2007. - № 7. pp. 23-29.

[8] Keynes, J.M. The general theory of employment, interest and money / J.M. Keynes; per. sang A.V. Grebennikov et al. - M .: ZAO Bizneskom, 2013. $402 \mathrm{sec}$.

[9] Holt, R.N. Fundamentals of financial management: Per. from English / R.N. Holt - M.: Delo, 1993. 126 p.

[10] Central Bank of the Russian Federation The main directions of the unified state monetary policy for 2016 and the period of 2017 and 2018. Approved by the Board of Directors of the Bank of Russia 10.11.2015. Access mode http://www.cbr.ru/publ/ondkp/on_2016\%282017-2018\%29.pdf

[11] Central Bank of the Russian Federation "Report on monetary policy." Information and analytical collection №4 2015.

[12] Bank of Russia website http://www.cbr.ru/analytics/print.aspx?file=bank_system/din_razv_15 _10.htm\&pid=bnksyst\&sid=ITM_1155

[13] Speech by the Chairman of the Bank of Russia E. Nabiullina in the State Duma on October 21, 2015 http://www.cbr.ru/Press/print.aspx?file=press_centre/Nabiullina_211 02015.htm\&pid=st\&sid=ITM_29912

[14] Federal Law "On Insurance of Deposits of Individuals in Banks of the Russian Federation". http://www.consultant.ru/document/cons_doc_LAW_45769/

[15] Liquidity of the banking sector and monetary policy instruments [Electronic resource]. Access mode: http://www.cbr.ru/statistics/?PrtId=idkp_br Date of appeal: 15.09. 2016 